
Mediated by Job Opportunity

Eka Yudha Sudrajad ${ }^{*}$ Postgraduate Scholar Program of Management Magistrate Economic Faculty, Gajayana University-Malang, Indonesia eka_yudha@gmail.com

\section{Dyah Sawitri}

Postgraduate Scholar Program of Management Magistrate, Economic Faculty, Gajayana University-Malang, Indonesia

\section{Djuni Farhan}

Postgraduate Scholar Program of Management Magistrate Economic Faculty, Gajayana University-Malang, Indonesia

${ }^{*}$ Corresponding author

\section{ABSTRACT}

Job opportunities and unemployment reduction become priority for human development in Malang City. Therefore, this study will examine the effect of job fair on unemployment reduction moderated by job opportunities. This study purposes are follow: 1) Knowing the effect of job fair on job opportunities in Malang City, 2) Knowing the effect of job fair on unemployment reduction in Malang City, 3) Knowing the effect of job opportunities on unemployment reduction in Malang City, 4) Knowing the effect of job fair on unemployment reduction mediated by job opportunities in Malang City. This is a survey research using explanatory research. This research was conducted in Malang City. This study used samples of 96 respondents. Data was collected using a questionnaire and filled in by respondents. From data obtained, a moderation analysis is done to examine the effect each variable. This research has four findings. First, job fair has positive and significant effect on job opportunities. Second, job fair has positive and significant effect on unemployment reduction. Third, job opportunities have positive and significant effect on unemployment reduction. Job opportunities mediated the effect of job fair on unemployment reduction.

Keywords: Job Fair, Job Opportunities, Unemployment Reduction, Malang City

\title{
INTRODUCTION
}

Manpower sector development is an integral part of national development (Mangkunegara, 2013). The aim is to implement the mandate of the 1945 Constitution, especially in article 27, paragraphs 2, on the right of every citizen to get a decent job and livelihood. Manpower sector development is related to activities of each sector, such as agriculture, industry, business, energy and transportation, which require a strong workforce. Considerable population growth and a low labour market reduce employment opportunities. This causes vulnerability and does not rule out the possibility of crime.

The efforts must be made for workers who enter the labour market to put into existing jobs to decrease unemployment (Dessler, 2015). The prolonged economic crisis has also 
exacerbated the problems faced by the government in development in the workforce sector. Unemployment is structural because unemployment occurred because of a mismatch between the worker's types offered and workers needed. Most unemployed individuals have low levels of education and limited skills; meanwhile, the demand for highly skilled workers increases rapidly (Safitri et al., 2018).

This discrepancy has occurred for many years. The policy made to cover the deficit of skills in the economy through the provision of high-quality education is deficient, and at the same time, structural changes took over the economy. The economic structure moves from the agriculture economy into the industrial sector for the developing countries. It is one most popular steps towards accelerating growth, including in Indonesia. The production process more focuses on technological advances that increase the demand for highly skilled workers at the expense of low skilled workers (Pauw et al., 2016).

The working-age of Malang City population in 2018 was 689,812 and continued to increase in 2019 to become 695,378. Meanwhile, the number of unemployed has a downward trend, wherein 2018 it was 30,898 people while in 2019 was 27,664. Even though there has been an unemployment reduction, the number of unemployed people is still relatively large. The government continues to strive to reduce unemployment.

The unemployment reduction does not mean that the employment problem in general and unemployment, in particular, will automatically be resolved. However, there was also a change in the composition of open unemployment during the same period (Sutrisno, 2016). Although the number of forces with higher education levels is small, it does not mean that all of them can be absorbed by labour market.

The city of Malang is known as the Students City. This nickname encourages the people of Malang to continue to improve the quality of education. This is evidenced by higher education achieved by the youth of Malang city. However, higher education is not always accompanied by ease of getting a job. Malang City remains a city with a relatively high unemployment rate. This condition needs to be taken seriously by all related agencies, both private and government. One of the efforts made by the Malang City government through the Manpower Office is to hold a Job Fair. The exhibition brings together job seekers and companies. The job fair is a medium for exploring the suitability of prospective workers and companies. Based on this phenomenon, researchers are interested in examining the effect of job fair employment opportunities and the impact on unemployment reduction in Malang City.

\section{THEORETICAL REVIEW}

\section{Labor Market}

Market is the physical location where the commodities are exchanged without compulsion in the transactions. The labour market puts the population in a dual role in the economy, the on-demand side as consumers of goods and services and the supply 
side as producers of goods and services. Population becomes consumers for goods and services. Population becomes producer with the role as entrepreneur or trader, or a worker at certain firms. The workers sell their energy to land and plantation owners. The wage rate is determined by the power of the worker over the employer. Some workers were so powerless that they did not even get paid, and their status was nothing more than a slave.

Acting as a trader who sells his labour services, a worker does not only give up an object outside him. They give parts of themselves, their muscle, and nerve and brain activity. Workers with higher education only go to work if the job gives money, status, or a relatively high level of satisfaction (Todaro, 2011). Qualitatively, the quality of the national workforce has increased due to two things: First, economic development at a certain level has succeeded in increasing people's income. Second, various policies in the national education sector have led to improvements in the quality of formal education in the workforce. However, subsistence sectors still dominated employment that did not need an educated workforce (Dessler, 2015). This gives rise to a supply induce symptom in which a large enough educated workforce puts intense pressure on job opportunities informal sector. At a macro level, this is also due to the transformation of economic structure from primary sector (agriculture) to secondary and tertiary sectors (industry and services), which is not followed by a transformation of labour absorption.

This symptom is due to the current industrial development pattern is based on national problems. Thus, in addition to building large-scale industries that are capital and technology-intensive, attention should also be given to industries development that is more oriented to absorb educated labour, which is prominent in number and multiplies (Dessler, 2015).

\section{Employment Opportunity}

Job opportunities are jobs available in the community. It can also be said that job opportunities are occupied jobs. Job opportunities are the people who work in a job or are absorbed in various economic sectors (Zainab \& Chris, 2014).

Population census data put the working people as a reflection of the job opportunities available. The job opportunities are not jobs that are still open. This last component will increase current job opportunities in future. There may be quite many job opportunities open at one time, while the number of job seekers is limited (Zainab \& Chris, 2014).

It can be concluded that job opportunities are indicated by the number of people who have worked. In other words, employment opportunities are the number of people who work in an economic situation of labour surplus. The job opportunities are reflected in some people who are absorbed in the process of economic activity.

\section{Unemployment}

Humans have a dual function in the dynamics of economic life. Humans become consumers (demand) who need goods and services and community as the owner of 
production factors (supply) to do the production process. Humans have two roles in the production process: a production factor (labour) and humans who work to provide services (Dessler, 2015).

The labour concept differs in a different countries. Indonesia conceptualizes the workforce to include people who are already or currently working, looking for work, and doing other activities such as going to school and taking care of the household. Residents classified as job seekers, go to school and take care of the household are considered physically capable and can work at any time.

Robbins \& Coulter (2016) defined unemployment in a macroeconomic sense as an unemployed workforce. Unemployment in the micro sense is defined as someone with capability and willingness to do work but is currently unemployed. Unemployed residents are looking for work or preparing for a new business or residents who have been accepted for work but have not yet started work.

\section{Conceptual Framework and Hypotheses}

The conceptual framework is a thought pattern from research to producing representative empirical research. The basis of the conceptual framework is theories, previous research, scientific studies and other information relevant to research. The conceptual framework of this study is presented in Figure 1.

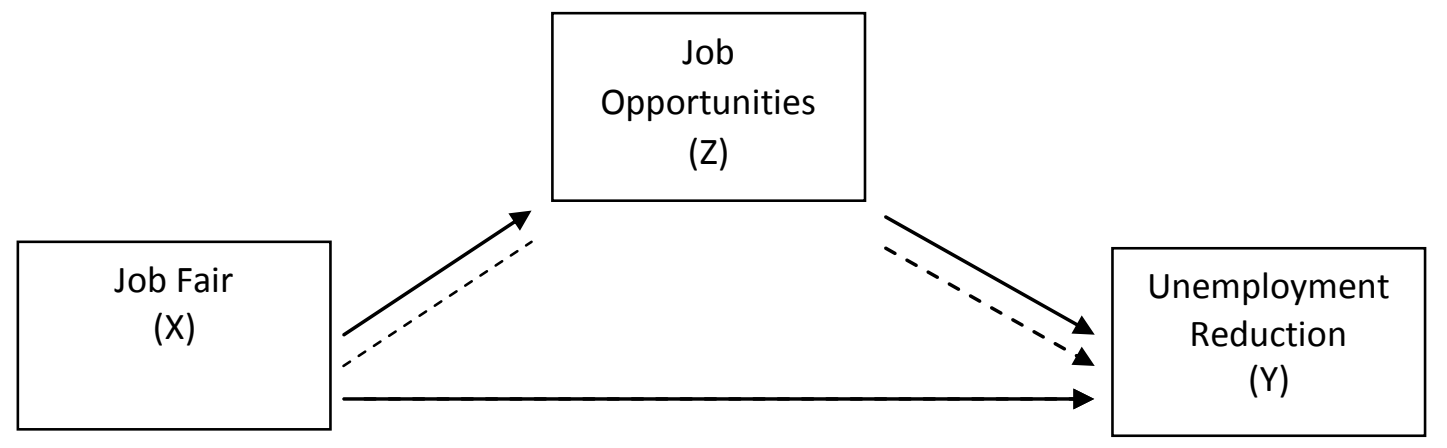

Description:

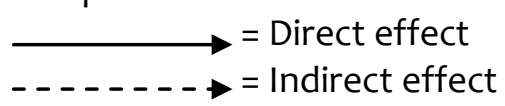

Figure 1. Conceptual Framework

The hypothesis of this research can be stated below.

H1: Job fair directly has a positive and significant effect on job opportunities in Malang.

$\mathrm{H}$ 2: Job fair directly has a positive and significant effect on unemployment reduction in Malang. 
H3: Job opportunities directly have a positive and significant effect on unemployment reduction in Malang.

$\mathrm{H} 4$ : Job opportunities mediate the effect of a job fair on unemployment reduction in Malang.

\section{METHODOLOGY}

This research was conducted in Malang City, East Java. The Manpower Office of Malang City is one of the government agencies engaged in the workforce sector that carries out job fair activities for the public or job seekers. This is evidenced by several school/university graduates who have benefited from these job fair activities. This research was conducted from October 2019 to December 2019.

It is explanatory or explanatory research. The research objects are job fair visitors in Malang City 2019 with a total of 2311 people. The sample was determined by the Slovin method (Umar, 2005) with 96 people. Data were collected using a 5-point Likert scale questionnaire, starting from 1 = strongly disagree, 2 = disagree, $3=$ neutral, $4=$ agree and 5 = strongly agree (Arikunto, 2013). To increase the response rate, two weeks after sending the questionnaire, a short message was sent via Whatsapp to ask the respondents to fill out the questionnaire. It is hoped that the message can increase the number of respondents who filled out the questionnaire and sent it back to the researcher.

The data obtained were analyzed using descriptive statistical analysis to describe the collected data is without intending to make generalized conclusions (Ferdinand, 2014), Ghozali (2014). Path analysis was performed using regression analysis followed by calculation of Sobel test for mediation test.

\section{RESEARCH RESULTS}

This study used a sample of 96 jobs, fair visitors in Malang. The majority of respondents are male (63.54 \%), aged between 21-30 (59.38\%), and the majority reached the level of education Bachelor (46.88\%) and Senior High School (36.46\%).

The validity and reliability level test was done to confirm the data validity and reliability. The instrument's validity would show that the collected data did not deviate from the description of the variables. The validity test shows that each variable's indicators are valid, as shown by Pearson coefficient correlation $>0.30$ and significant at 0.000 . Meanwhile, the reliability test shows all instruments are reliable, as indicated by Cronbach's alpha value greater than 0.6 . These results indicate that all statements in the questionnaire can be used in further analysis.

Hypotheses are tested by regression analysis for the influence of job fairs $(X)$ and job opportunities ( $\mathrm{Z}$ ) on unemployment reduction (Y). Table 1 and Table 2 shows the test results. 
Table 1. Multiple Regression Analysis for $\mathrm{X}$ to $\mathrm{Z}$

\begin{tabular}{|c|c|c|c|c|c|c|}
\hline Variable & $\begin{array}{l}\text { Regression } \\
\text { coefficient } \\
\text { (b) }\end{array}$ & $\begin{array}{l}\text { Standard } \\
\text { deviation. } \\
\text { (B) }\end{array}$ & $\operatorname{Error}_{(\beta)}^{\text {Beta }}$ & $\mathrm{t}_{\text {count }}$ & Sig. & Description \\
\hline Constant & 6.378 & 1.474 & & 4.327 & .000 & \\
\hline$x$ & .552 & .083 & .566 & 6.658 & .000 & Significant \\
\hline \multicolumn{2}{|c|}{$\begin{array}{l}\text { Dependent variable } \\
\text { R Square } \\
\text { e1 }\end{array}$} & \multicolumn{5}{|c|}{$\begin{array}{l}=\text { Job opportunities }(Z) \\
=0.32 \\
=1-R^{2}=1-0.32=0.68\end{array}$} \\
\hline
\end{tabular}

Table 2. Multiple Regression Analysis for $\mathrm{X}$ and $\mathrm{Z}$ to $\mathrm{Y}$

\begin{tabular}{|c|c|c|c|c|c|c|}
\hline Variable & $\begin{array}{l}\text { Regression } \\
\text { coefficient } \\
\text { (b) }\end{array}$ & $\begin{array}{l}\text { Standard } \\
\text { deviation. } \\
\text { (B) }\end{array}$ & Error $_{(\beta)}^{\text {Beta }}$ & $\begin{array}{l}\text { Do } \\
\text { count }\end{array}$ & ${ }^{\text {not }}$ Sig. & Information \\
\hline Constant & 5.045 & 1.520 & & $3 \cdot 319$ & .001 & \\
\hline X & .225 & .095 & .238 & 2.381 & .019 & Significant \\
\hline Z & .428 & .097 & .440 & 4.403 & .000 & Significant \\
\hline \multicolumn{2}{|c|}{$\begin{array}{l}\text { Dependent variable } \\
\text { R Square } \\
\text { e1 }\end{array}$} & \multicolumn{5}{|c|}{$\begin{array}{l}=\text { Unemployment reduction }(\mathrm{Y}) \\
=0.369 \\
=1-\mathrm{R}^{2}=1-0.369=0.631\end{array}$} \\
\hline
\end{tabular}

The regression analysis results for job fair $(X)$ effect on unemployment reduction $(Z)$ are explained following proposed hypothesis testing.

Hypothesis $\mathrm{H} 1$

Hypothesis $\mathrm{H} 1$ states that job fair directly has a positive and significant effect on the job opportunities of job fair visitors in Malang. Table 1 indicates that job fair (X) has a beta coefficient of $0.566, t$ values of 4.327 and significance ( $p$-value) of $0.000<0.05$. This means that $\mathrm{H} 1$ is accepted. The job fair $(X)$ directly has a significant and positive effect on job opportunities. Better job fairs $(X)$ can increase job opportunities.

Hypothesis $\mathrm{H}_{2}$

Hypothesis $\mathrm{H} 2$ states that job fair directly has a positive and significant effect on the unemployment reduction of job fair visitors in Malang. Tabel 2 shows that the variable Exhibition labour market $(X)$ has a beta coefficient of 0.238 , $t$ values of 2.381 and significance (p-value) of $0.019<0.05$. H2 accepted. The job fair $(X)$ directly has a significant and positive effect on an unemployment reduction of 0.238 . More jobs fair (X) can reduce unemployment. 
Hypothesis $\mathrm{H}_{3}$

Hypothesis $\mathrm{H}_{3}$ states that Job opportunities directly have a positive and significant effect on unemployment reduction of job fair visitors in Malang. Table 2 indicates that variable Employment reduction $(\mathrm{Y})$ has a beta coefficient of 0.440 values of 4.403 and significance ( $p$-value) of $0.000<0.05$. H3 is accepted. Better job opportunities (Z) can reduce unemployment $(\mathrm{Y})$.

Hypothesis 4

Hypothesis 4 states that job opportunities mediate the effect of a job fair on unemployment reduction of job fair visitors in Malang. The indirect effect of the job fair $(\mathrm{X})$ variable on unemployment reduction $(\mathrm{Y})$ is calculated through job opportunities $(\mathrm{Z})$. The indirect effect of the independent variable on the dependent variable can be determined by multiplying the value of the direct effect (standardized beta coefficient) in each equation. Table 3 shows the results.

Table 3. Mediation Testing

\begin{tabular}{|c|c|c|c|c|c|}
\hline & Direct & Indirect & Sig. Value & Information & \\
\hline$X-Z$ & 0.566 & - & 0.00 & $\begin{array}{l}\text { Positive } \\
\text { significant }\end{array}$ & and \\
\hline$X-Y$ & 0.238 & - & 0.00 & $\begin{array}{l}\text { Positive } \\
\text { significant }\end{array}$ & and \\
\hline$Z-Y$ & 0.440 & - & 0.00 & $\begin{array}{l}\text { Positive } \\
\text { significant }\end{array}$ & and \\
\hline$X-Z-Y$ & - & $\begin{array}{l}0.238+( \\
0.440)=\end{array}$ & & $\begin{array}{l}\text { Positive } \\
\text { Significant }\end{array}$ & and \\
\hline
\end{tabular}

The above calculations results can be explained below.

$\mathrm{X}$ directly has a significant and positive effect on $\mathrm{Z}$ at 0.566 .

$\mathrm{X}$ directly has a significant and positive effect $\mathrm{Y}$ at 0.238 .

$Z$ directly has a significant and positive effect on $Y$ at 0.440 .

$X$ indirectly has a significant and positive effect on $Y$ mediated by $Z$ at 0.483 .

\section{DISCUSSIONS}

\section{Direct Effect of Job Fair on Job Opportunities}

Job fairs directly have a significant and positive effect on job opportunities of job fair visitors in Malang. Job fair visitors will have an impact to increase job opportunities. These study results are consistent with research conducted by Buchsa et al. (2017), who found that job fairs can increase job opportunities based on mutual trust. 


\section{Direct Effect of Job Fair on Unemployment reduction}

The job fair directly has a significant and positive effect on the unemployment reduction of job fair visitors in Malang. Implementing a job fair can make the fair job visitors in Malang have better job opportunities and reduce unemployment. The job fair exhibits make job fair for visitors in Malang easier to find a job. These study results are consistent with Sengul (2017) that job fairs can reduce unemployment. Higher job opportunities themselves ultimately has an impact on reducing unemployment.

\section{Direct Effect of Job Opportunities on Unemployment Reduction}

Job opportunities directly have a significant and positive effect on unemployment reduction of job fair visitors in Malang. Higher job opportunities can reduce the unemployment of job fair visitors in Malang. High job opportunities will certainly make job fair visitors in Malang the best contribution to increase job opportunities. This contribution will certainly make visitors more needed and appreciated. This will make them study even more complex. These study results are consistent with Robin and Murtin (2018) that job opportunities will reduce unemployment.

\section{Indirect Effect of Job Fair on Unemployment reduction through Job Opportunity}

Testing the indirect effect of a job fair on unemployment reduction job opportunities as a mediation variable shows a positive and significant result. The result of this indirect effect shows a more excellent value than the direct effect. This shows that through the job opportunities, the indirect effect of a job fair on unemployment reduction is higher. Job fair directly affects job opportunities. Job opportunities also mediate the effect of a job fair on unemployment reduction. Because both have a significant effect, this mediation is partial; both direct and indirect effects are equally significant. The results of this study are consistent with Sengul (2017), Buchsa et al. (2017), and Robin and Murtin (2018) that job fairs will increase job opportunities which in turn reduce unemployment.

\section{CONCLUSIONS}

Job fair directly has a significant and positive effect on job opportunities. This means that the right job fair will increase job opportunities for job fair visitors in Malang. Job fairs directly have a significant and positive effect on unemployment reduction. This means that the right job fair can reduce unemployment among job fair visitors in Malang.

Job opportunities directly have a significant and positive effect on Unemployment reduction. Good job opportunities can reduce unemployment among job fair visitors in Malang. Job fairs indirectly have a significant effect on unemployment reduction mediated by job opportunities. This means that job fair indirectly affects the unemployment reduction mediated by job opportunities of job fair visitors in Malang.

The organizers of a job fair in Malang should increase job opportunities and reduce unemployment by determining the job fair according to the needs. Therefore, job fairs

172 Management and Economics Journal (MEC-J)

Vol 5 (2) August 2021 
should be held based on needs to increase job opportunities and reduce unemployment. Future researchers should improve the generalization of theory by adding three things. First, increasing the number of samples by including the scope of East Java or the national level. Second, this study only uses the fair job variable as an independent variable. Other variables affect job opportunities and unemployment reduction outside the job fair, such as work experience, education, and compensation. Therefore, these variables can be added to future research. Third, this research uses Path Analysis with multiple regression analysis that only examines the relationship between variables. It does not disclose the relationship between indicators of each variable, especially the causal relationship between indicators Exhibition labour market against indicators of employment reduction and job opportunities. Therefore, the future researcher should use better analysis tools as Smart PLS.

\section{REFERENCES}

Arikunto, S. (2013). Prosedur Penelitian Suatu Pendekatan Praktik. Jakarta: PT.Rineka Cipta

Buchsa, H., Emily, M., Marlis, B. (2017). Landing a job, sinking a career? The trade-off between occupational downgrading and quick reemployment according to unemployed jobseekers' career stage and job prospects. Research in Social Stratification and Mobility, 52: 26-35

Dessler, G. (2015). Manjemen Sumber Daya Manusia. Edisi keempat belas alih bahasa Diana Angelica. Salemba Empat. Jakarta

Fatkhudin, Aslam, Imam Rosyadi, Nur Hesti Sulistyowati. (2016). Sistem Informasi Job Fair Pada Dinas Sosial Tenaga Kerja dan Transmigrasi Kota Pekalongan Berbasis Web. SAINTEKBU: Jurnal Sains dan Teknologi, 8(1), 15-25.

Ferdinand, A. (2014). Metode Penelitian Manajemen. Semarang: Badan Penerbit Universitas Diponegoro.

Ghozali, I. (2014). Aplikasi analisis Multivariate dengan Program SPSS. Semarang: Badan Penerbit UNDIP.

Mangkunegara, Anwar Prabu. (2013). Manajemen Sumber Daya Manusia Perusahaan. Bandung: PT. Remaja Rosadakarya

Pauw, Kalie, Morne Oosthuizen and Charlene van der Westhuizen. (2016). Graduate Unemployment in the Face of Skills Shortage : A Labor Market Paradox. South Africa : Development Policy Research Unit.

Robbins, Stephen P. and Coulter, M. (2016). Manajemen, Jilid 1 Edisi 13, Alih Bahasa: Bob Sabran Dan Devri Bardani. Jakarta: Erlangga.

Robin, Jean-Marc and Fabrice Murtin. (2018). Labor market reforms and unemployment dynamics. Labour Economics 50: 3-19.

Safitri, M., Aldhila, N. dan Astrid, N. (2018). Sistem Informasi Lowongan Kerja Berbasis Web. Jurnal PILAR Nusa Mandiri. 14(1), 49-54 
The Effect of Job Fair on Unemployment Reduction.....

Sengul, G. (2017). Effect of labor market policies on unemployment when firms adapt their recruitment strategy. Economic Modelling Volume 60: 169-179

Sutrisno, E. (2016). Manajemen Sumber Daya Manusia. Cetakan ke-8. Jakarta : Prenada Media Group

Todaro, M. P. (2011). Pembangunan Ekonomi di Dunia Ketiga. Jakarta: Erlangga.

Umar, H. (2005). Metode Penelitian Untuk Tesis Dan Bisnis. Jakarta: Grafindo Persada.

Zainab, B. dan Chris, M. (2014). Angkatan Kerja di Indonesia : Partisipasi, Kesempatan dan Pengangguran. Jakarta: Rajawali 